\title{
Smart Campus with the Big Data
}

\author{
Jianhua ZHANG ${ }^{1, a_{*}, \text { Yijing XU }}{ }^{2, b}$ \\ ${ }^{1}$ General Education Center, Beijing Normal University Zhuhai Campus, China \\ ${ }^{2}$ General Education Center, Beijing Normal University Zhuhai Campus, China \\ a zhuhaijianhua@aliyun.com, ${ }^{b}$ 845443202@qq.com,
}

Keywords: Big data; Smart education; Smart campus

\begin{abstract}
After Chinese universities implementation the basic engineering "digital campus", now is needed to resolve how to make use of modern information technology to education reform. This paper talk about what are smart education and smart campus, and then to point out the difficulties in Implementation of works now, finally put forward anther's suggestion.
\end{abstract}

\section{Introduction}

Informational education is an important part of the national economy and informational social, under countries and education sectors under the unified planning and organization, in all areas of the education system make full use of information technology, development of utilization of information resources, to promote the exchange of information and knowledge sharing, and promote the process of the modernization of education.

From 2006 to 2010, the CPC central committee and the state council formulated the "national medium and long-term education reform and development compendium (2010-2020)" and other documents, the file points out that Information technology revolutionary influence on education development, we must pay attention to it, and clear requirements to accelerate the process of informational education [2].

In order for fully reflect the status of development of informational education in our country, Provide support and reference for Chinese informational education construction, the ministry of education in January 2013, organized a nationwide informational education development research meeting, to discuss the overall development situation of our country informational education.

Infrastructure begun to take shape. China education satellite broadband transmission network (CEBSat) and telecom operators of network as the main support of education information network has begun to take scale. CERNET connected to more than two thousand education and scientific research institutions, the user more than twenty million people, the popularization of campus network in colleges and universities, Some primary and middle school campus network and information-based teaching equipment improve, this make education resources development and application of gradually deepened, and laid a solid foundation.

Continue to strengthen personnel training. College and university information technology and related professional students now more than 300 million people, more than 500 million students in Vocational College of information technology and related professional, information technology and junior high school education get comprehensive promotion.

Information system and the application of management information system in the university comprehensive promotion. Related statistics: by the end of 2012 , nearly about $93.85 \%$ of higher schools already use the basic information application system, more than $90 \%$ of university there are library information system and teaching educational administration information system, office automation system, equipment assets management information system, of student management information system and so on. 


\section{Smart Education and Smart Campus}

In 2012, Tsinghai University press published a book", Smart Education", edited by He Xiao professor [5]. Maybe, this is the first book to talk about education concept and characteristic \& core content of smart education.

Since the book published more than three years time, the modern information technology brings the impact and influence of the science education can even use the word" education revolution " to describe. Based on cloud computing [6], based on large data processing and data mining, the "Smart Education" meaning, can already be following such a statement: Smart education is the informational education, is refers in the field of Education including education management, education teach science research and education teaching, comprehensive in-depth use of modern information technology to facilitate the process of the reform and development of education. Its technical features are digital, networking, intelligent and multimedia, the basic feature is open, sharing, interaction, collaboration. To promote the modernization of education and information technology to change the traditional model [7].

So that there is "smart campus" [8] the new vocabulary, the vocabulary equal to "Smart Education ", and it is already can instead of "Smart Education", and is more popular vocabulary now.

My understanding of the "smart campus" is: it is under reform of education, covers the "smart teaching, smart learning, smart management, smart evaluate, smart scientific research and smart services", the education application of mode a new generation of education system.

\section{The difficulty on the implementation of "smart campus"}

Due to information technology management systems was gradual setting up in past ten years. this teaching departments and various units, their various management systems rely on computer operating systems, application development platform, database management system, basic metadata and types, data acquisition standards, data processing and data integration forms, even the final output display mode is different.

Based on the above situation, various information system and information utilization rate is extremely low, also there is a information island phenomenon.

Big data has four characteristics as general awareness of the people: Volume, velocity, variety and value, in addition, " it is private data" [10] feature is can't avoid, this is a major difficulty to process for the "smart campus". For example, some investigation is or not to involved in the invasion of the students' personal privacy? In addition, all the relevant data can be opened? This for the implementation of smart campus of engineering and technical personnel concerned is a insurmountable " gap ", will lead them impossible to complete the task. There are a lot of things as this.

The talent shortage, and the teachers of shortage, school of the shortage of financial and material resources, is ordinary institutions of higher learning difficulties of implementation of the "smart campus" work.

\section{The future work direction}

The specific work to be feasible. As director of education work of the leadership and education workers, to carefully analyze the advantages and difficulties of the current working place. And for the current work in accordance with the "overall planning, resource integration, data sharing, focusing on application of" the principle of steady progress, have achieved practical results.

Strengthen intercollegiate mutual learning and communication, is a good thing. to set the big data processing and data mining course as the main content of general elective course in university, it's a good plan to accelerate and strengthen the personnel training.

Please students to participate in the relevant scientific research work. Please students to participate in the relevant scientific research work is not only to give students experience practice chance, but also for teachers' scientific research work provides the more assistant. 
The school and enterprise cooperation. "The school and enterprise cooperation" is the effective use of education resources, improve school comprehensive strength, is one of realizes university rapid developing good idea

\section{Summary}

After Chinese universities implementation the basic engineering "digital campus", now is needed to resolve how to make use of modern information technology to education reform.

And on the other hand, in the face of new teaching methods and methods, new teaching organization form, new teaching resources, new teaching ideas, new ways of running schools, teachers' roles have been changed. These changes will be reflected in the overall process of teaching, the object of service is students, as "master"; teachers are as "waiter". Moreover, teachers must have the following capabilities: first, teachers should adapt to the modern teaching methods; followed by, teachers must be familiar with and master the modern teaching aid, and includes wireless communication tools, such as blog, twitter, e-mail, Wechat and so on; third, teachers must have more extensive knowledge and profound foundation of professional and academic level of higher; fourth, teachers should be in the ideological understanding, advancing with the times, to keep up with the pace of development of the times, correct understanding of this unprecedented education reform, and actively involved.

\section{References}

[1] Information on http://phycjy.pinghu.gov.cn/readnews.asp?id=3121

[2] Information on http://edu.ifeng.com/news/detail_2010_07/30/1859314_2.shtml

[3] Information on http://edu.ifeng.com/news/detail_2010_07/30/1859130_0.shtml

[4] Information on http://baike.baidu.com/view/3496.htm

[5] Information on http://item.jd.com/10914601.html

[6] Information on http://baike.baidu.com/view/1316082.htm

[7] Information on http://news.xinhuanet.com/info/2013-09/30/c_132764225.htm

[8 ]Information on http://baike.baidu.com/view/5478486.htm

[9] Information on http://baike.baidu.com/subview/6954399/13647476.htm

[10] Information on http://wenku.baidu.com/view/47dd86205901020207409c24.html

[11] Information on http://edu.ifeng.com/gundong/detail_2010_07/17/1787134_0.shtml

[12] Jianhua Zhang, Zhe Zhang, Zhen Ge, General Education and Internet, Advances in Education Research/ Volume 22/ p.68

[13] Zhe Zhang, Jianhua Zhang, Zhen Ge, Comparison of Chinese and German Higher Education, Advances in Education Research/Volume 22/ p.81

[14] Jianhua Zhang, Zhen Ge, General Education and Practice in University, Advances in Education Research/ Volume 4/ p.158 